\title{
New Preface to NEW MASTERS
}

It's hard to believe that eighteen years have elapsed since this book first appeared in print, and even harder to imagine what was going through my mind when I took the subject on. I can remember what sparked my initial interest: the excitement of reading for the first time Willie Lee Rose's Rehearsal for Reconstruction for C. Vann Woodward's graduate seminar on the New South. Ms. Rose's account of clashing expectations between liberator and liberated in the postage-stamp arena of wartime Port Royal, South Carolina, brought history alive in a way that academic books seldom do. I needed a dissertation topic. The post-Civil War travel literature hinted that the free enterprisers who comprised part of Ms. Rose's study were hardly confined to the Sea Islands south of Charleston. The story looked worthy of expanding, provided source material could be found. As it happened, it was available in embarrassing abundance. So I plunged in.

Vaguer in memory are the broader influences on my choice of a topic. Most vivid are the political upheavals of the late 1960s and early ' 70 s. It was a disconcerting time to be in graduate school, to say the least. The cities were on fire; universities, on strike. Antiwar marchers thronged the streets of Washington. American innocence lay in shambles in the wake of the assassination of the Kennedy brothers and Dr. King. Racism had been rediscovered, as had class and poverty. It was as though all the icons of my boyhood had fallen with the abruptness of monuments being pulled from their plinths and pedestals.

The unrest affected how my generation approached history. We wanted it to be relevant. We wanted usable role models. And in some undefined way we wanted to stamp our generational identity on the way the past was interpreted and understood.

The intellectual ferment revolutionized received historiography. For what I learned in high school and college was not what I learned in graduate school. What I learned as an undergraduate was consensus history, variations on the theme that Americans had never seriously disagreed over ideology and that capitalism, having arrived on the first ships, was predestined to prevail in whatever form. The viewpoint was well suited to the prosperous 1950 s, when it looked as though the American Century might last forever. By the time I reached graduate school, however, that easy optimism had been badly shaken by international and domestic setbacks, and consensus history had come under sustained attack.

Many of the broadsides came from historians who were more attuned to ideology than were their predecessors. In the 1960s they had discovered an alternative 
to Lockean liberalism. They termed this alternative political tradition "classical republicanism." Classical republicanism was refreshing in its insistence that community came before profit. It was even more appealing in its corollary assumption that a republic's political health and well-being depended on a broad distribution of productive property; that is, on the economic and political empowerment of the common man. Nothing here heralded the inevitable triumph of corporate capitalism. In other words, there had been alternatives, roads not taken. We took heart. Around the same time, practitioners of the "new" social history, largely influenced by the moral and intellectual example of the neo-Marxist historian E. P. Thompson, were energetically rewriting the past from the bottom up, discovering dissenting voices aplenty in antebellum artisans, yeomen farmers, and southern slaves.

It was exciting stuff, and during the extended coffee breaks and evening beer sessions that often pass for graduate training, my generation discussed and debated the new literature as if the Rosetta Stone itself had been dropped into our laps.

Meanwhile, Reconstruction revisionism had been proceeding on a separate line of attack. This historiographical offensive had been underway since the 1930s - partly a campaign of the Old Left (as distinct from the New Left of the 1960s). A lot of the corrective work had been completed by the time my generation took aim at the post-emancipation South. Reconstruction revisionists had razed the racial and sectional mythology that had propped up the old Dunningite ${ }^{1}$ interpretation. The new overview was a model of common sense and balanced reasonableness. There was one problem, as we saw things: the new interpretation looked like an inversion of what had stood before. Erstwhile villains such as the carpetbaggers and scalawags weren't the penniless scoundrels of Reconstruction lore. State Republican governments weren't unrelievedly corrupt. The redeemers who overthrew Reconstruction, often by extralegal fraud and violence, weren't good government Galahads in shining armor. Black Reconstruction wasn't all that black. The new interpretation was a series of negations.

Surely there was more to it than that, we insisted in our callow youth.

One question nettled us above all others. It still bedevils modern scholarship on the subject: why did Reconstruction fail? Evidence had just appeared from both ends of American history indicating that racism was deeply woven into the social fabric. ${ }^{2}$ What with our demands for relevance, we were sure that contemporary America's problems with race and poverty had a lot to do with the preceding century's most egregious failures. The conviction made us impatient, maybe even selfrighteous. Why did nineteenth-century abolitionists and radical Republicans fail to erase racism? Why did free labor and free enterprise fail to introduce democratic prosperity to the prostrate South?

For that matter, why did the triumphalist North balk at remaking the plantation South in the image of the small-farm North if classical republicanism was the litmus test of political and economic well-being?

${ }^{1}$ After William Dunning, the influential Columbia University historian whose Ph.D. students early in this century enshrined the negative version of Reconstruction in the nation's textbooks.

${ }^{2}$ See Winthrop Jordan's searching investigation of the origins of American racism, White Over Black: American Attitudes Toward the Negro, 1550-1812 (Chapel Hill, 1968); and the Report of the National Commission on Civil Disorders (Washington, D.C., 1968), commonly known as the Kerner Report. 
Eric Foner's Reconstruction: America's Unfinished Revolution has since addressed these questions in masterful fashion. But at the time of the writing of $\mathrm{New}$ Masters, our understanding of the larger dynamic that molded Reconstruction was still inchoate. At least my understanding was. My own tentative stab at an answer was that the ethos and ambitions of the young men who had flocked South for profit and principle held a partial key. Well-born and well-educated, these Yankee sojourners were the best and the brightest of their generation, the cream of the new northern middle-class then coming to power in postbellum America. If ever a social group offered an early indication of what the limits of liberal reform might be toward the vanquished South, it was these young free labor pioneers.

And what motivated them to take up temporary residence in Dixie? New Masters argued that the primary motive was not to revolutionize the plantation order, but to perpetuate it. It was not to uplift the ex-slaves (though many hoped to improve the freedmen's lot), but to profit from their labor. The freedmen refused to play their roles, for the ex-slaves had their own agenda, and it was not to earn quick profits for their liberators. So, in frustration and disgust, northern planters embraced a cultural racism all too familiar to our own time. If African Americans were unable to bootstrap themselves into farm ownership, it must be because of ingrained deficiencies in ambition, self-discipline, and thrift-virtues celebrated by the free-labor creed. The fault, in other words, must lie with the victims, not the social and economic character of the new order.

New Masters has been criticized on two counts: first, that it overestimates the number of northerners who became involved in cotton cultivation during and after the war; second, that it claims too much for its limited subject. To the first charge I wish to enter a plea of guilty. LaWanda Cox caught me out on this one. I asserted, in a moment of high enthusiasm, that anywhere from twenty to fifty thousand northerners invested in southern cotton plantations during the Civil War and Reconstruction. I said this was "an informed hunch." As it happens, it was not all that informed. In the six Deep South states on which New Masters focused, according to the 1860 census, there were only slightly more than 28,000 plantations, hardly enough to accommodate all the fortune seekers I estimated to have been in the market, even allowing for joint business ventures. ${ }^{3}$ If $\mathrm{I}$ had it to do over again today, I'd probably place the number at from five to seven thousand, and maybe slightly more to include the silent investors back home. But having made this concession, I don't see any reason to back down from the main point, which is that northern planters were ubiquitous-indeed, more numerous than many of the better known actors in the Reconstruction drama.

As for the charge of overstretching the evidence, the jury must remain out on this one. That northern investments shored up the plantation system at a critical juncture seems beyond cavil. That northern-run plantation stores influenced the eventual emergence of merchandising and credit as means for extracting the agricultural surplus of a landless peasantry also strikes me as indisputable. The only problem is, as my critics have argued, there is no reason to believe a different outcome might have obtained in the absence of northern investors and planters. The forces driving the emergence of tenancy and the crop lien were impersonal: capital scarcity, black poverty and powerlessness, stagnant cotton demand, and expanding

\footnotetext{
${ }^{3}$ See her review of New Masters in The Alabama Review (April 1981), 136-39.
} 
rail service. These were the major factors that molded the new order in the postwar South, not the activities of northern speculators. Even so, Yankee enterprise and capital played a part. Maybe their role wasn't indispensable; maybe it wasn't even crucial. But the fact that Yankees played a role at all underscores the barriers in the way of exporting social revolution to the defeated Confederacy.

There is the final matter of my suggesting that the northern planter movement was a metaphor for the demise of radical Reconstruction and the colonial development of the New South. Here is where I climbed farthest out on the limb. The movement I wrote about was effectively over nine years before the final curtain rang down on the Reconstruction drama, and several decades before the New South finished taking shape. How could the shooting-star interlude examined in $\mathrm{New}$ Masters be a harbinger of both Redemption and New South neo-colonialism? My only excuse for making the claim - and it was offered almost en passant-is that I was writing figuratively, seeing in the hothouse experience of Yankee planters a prefigurement of the economic and psychological dynamic of a sectional reconciliation that culminated later in the nineteenth century.

I wish I could rewrite the throwaway claims about the economic colonialism. New Masters is too restricted in scope to offer much to that debate. But I regret nothing I said concerning the racial dynamic between Yankees, freedmen, and white southerners. After all, reconciliation between white northerners and white southerners has often been at the expense of African-American rights and liberties. In the nineteenth century the abandonment of the first Reconstruction culminated in the 1896 Plessy v. Ferguson decision, which placed a stamp of national approval on a fast solidifying system of racial segregation in the American South. The contemporary retreat from the milestones of the Civil Rights movement is likewise marked by any number of recent U.S. Supreme Court decisions. Now, as then, the betrayal is justified in the language of equal rights. And now, as then, it is underpinned by the assumption that African Americans should enter the competitive race without compensatory assistance, even though the starting line for them is far behind that for whites. Yankee planters uttered the same thing when they returned home more than a century ago poorer in purse. In that sense, they sadly prefigured the shape of things to come, exemplifying the deeper rhythms of race and class that continue to drive the cycle of American race relations. 